\title{
THE FINANCIAL LEGACY OF AFGHANISTAN AND IRAQ: HOW WARTIME SPENDING DECISIONS WILL CONSTRAIN FUTURE U.S. NATIONAL SECURITY BUDGETS
}

\section{LINDA J. BILMES}

Linda J. Bilmes is Daniel Patrick Moynihan Senior Lecturer in Public Policy at the John F. Kennedy School of Government, Harvard University, Cambridge, MA, USA. Previously serving as Assistant Secretary and Chief Financial Officer of the U.S. Department of Commerce, she may be reached at linda_bilmes@harvard.edu.

\section{Abstract}

The Afghan and Iraqi conflicts, taken together, will be the most expensive wars in United States history, totaling somewhere between US\$4 to US\$6 trillion. This includes long-term medical care and disability compensation for service members, veterans and families, military replenishment, and social and economic costs. The largest portion of that bill is yet to be paid. Since 2001, the U.S. has expanded the quality, quantity, availability, and eligibility of benefits for military personnel and veterans. This has led to unprecedented growth in the Department of Veterans Affairs and the Department of Defense budgets. These benefits will increase further over the next 40 years. Additional funds are committed to replacing large quantities of basic equipment used in the wars and to support ongoing diplomatic presence and military assistance in Afghanistan and Iraq. The large sums borrowed to finance war-related operations will also impose substantial long-term debt servicing costs. As a consequence of these wartime spending choices, the United States will face constraints in funding investments in personnel and diplomacy, research and development, and new military initiatives. The legacy of decisions taken during the Afghan and Iraqi wars will dominate federal budgets for decades to come.

$\mathrm{O}$ ne of the most significant challenges to future United States national security policy will not originate from any external threat. Rather it is simply coping with the legacy of the conflicts already fought in Afghanistan and Iraq. This legacy is debt - promises and commitments that extend far into the future. The war years have left the United States burdened with heavy costs, even with the ground combat phase drawing to a close. ${ }^{1}$ These costs include the immediate requirements to provide medical care for the wounded, as well as the accrued liabilities for providing lifetime medical costs and disability compensation for those who have survived injuries. Long-term costs also include structural increases to the military personnel and health care systems, depreciation on military equipment and weaponry, restoring the military, Reserves, and National Guards to prewar levels of readiness, and maintaining a long-term military and diplomatic presence in the region. There are also far-reaching social costs, including the costs of impaired quality of life, families damaged and careers terminated, as well as economic and financial costs that have been estimated (with Joseph E. Stiglitz) in previous writings. $^{2}$

The United States has already spent close to US\$2 trillion in direct outlays for expenses related to Operation Enduring Freedom, Operation Iraqi Freedom, and Operation New Dawn. This includes direct combat operations, reconstruction efforts, and other direct war spending by the Department of Defense, State Department, Department of Veterans Affairs, and Social Security Administration. ${ }^{3}$

However, this represents only a fraction of the total war costs. The single largest accrued liability of the wars in Afghanistan and Iraq is the cost of providing medical care and disability benefits to war veterans. Historically, the bill for these costs has come due many decades later. For instance, the peak year for paying disability compensation to veterans of the first world war was in 1969-more than 50 years after Armistice. The largest expenditures for veterans of the second world war were in the late 1980s. ${ }^{4}$ Payments to Vietnam and first Gulf war veterans are still climbing. The magnitude of future expenditures will be even higher for the current conflicts, which have been characterized by much higher survival rates, more generous benefits, and new, expensive medical treatments. The United States has also expanded veteran's programs, made it easier to qualify for some categories of compensation, and invested in additional staff, technology, mental health care, medical research, and other services designed to improve the situation of newly returning veterans.

The percentage of service members who have required medical care from the Pentagon and VA systems, and who have claimed benefits from the VA and the Social Security 
Disability Insurance program (SSDI) has risen to unprecedented levels. More than half of the 1.56 million troops who have been discharged to date have received medical treatment at VA facilities and been granted benefits for the rest of their lives. ${ }^{5}$ The costs of providing for these veterans, however, are only a portion of the total accruing personnel and health care costs for the military. Military members and their families are eligible for health coverage through the TRICARE system, which has been growing at an even faster rate than the VA health care system. These accrued wartime liabilities, which have already been incurred but not yet paid, should be considered as an integral part of the overall war costs.

There are substantial social-economic costs that accompany these statistics. If fatalities are accounted for in the same way that U.S. civilian agencies value a life, the value of lives lost adds US $\$ 44.6$ billion to the cost of the wars. This is the difference between the so-called Value of a Statistical Life (VSL) per life lost, compared with the actual budgetary cost to the Pentagon of paying life insurance and a "death gratuity" to survivors. ${ }^{6}$ Other social-economic costs arise from the large number of service members whose lives have been disrupted by physical injuries or mental health disabilities. There are costs to the service members and to their families; in many cases, family members have needed to become full-time caregivers or to significantly alter their employment. These costs are not paid by the government, but are borne by the individuals, families, and communities.?

The Pentagon also faces the task of replacing worn-out equipment, which will cost more than the amounts appropriated for this purpose. Equipment, materiel, vehicles, and other fixed assets have depreciated at an estimated six times the peace-time rate, due to heavy utilization, poor repair and upkeep in the field, and the harsh conditions in the region. Even the logistics and cost of transporting equipment out of Afghanistan is predicted to cost billions. ${ }^{8}$ The U.S. has also made long-term commitments to the security of Afghanistan including a Strategic Partnership Agreement signed by President Obama and Afghan President Hamid Karzai in 2012 to provide U.S. support through $2024 .{ }^{9}$

Finally, the decision to finance the war operations entirely through borrowing has already added some US $\$ 2$ trillion to the national debt, contributing about 20 percent of the total national debt added between 2001 and 2012. ${ }^{10}$ This level of debt is thus one of the reasons the country faces calls for austerity and budget cuts, which has already had an impact on the military budget through the across-the-board cuts (the "sequester") that were allowed to take effect in 2013. The U.S. has already paid US\$260 billion in interest on the war debt. This does not include the interest payable in the future, which
One of the most significant challenges to future United States national security policy will not originate from any external threat. Rather it is simply coping with the legacy of the conflicts already fought in Afghanistan and Iraq. This legacy is debt.

will reach into the trillions. ${ }^{11}$

This article will focus on the costs of commitments we have made in four important areas during the Afghan and Iraqi wars: (1) veterans health care and disability compensation; (2) Pentagon personnel and health care policies and benefits; (3) other Department of Defense costs and commitments; and (4) the financing of the wars.

The data presented here update previous estimates for the care of Afghanistan and Iraq veterans based on actual reported data through calendar year-end 2012. It also estimates additional costs that were not considered in previous estimates, including costs incurred by the Department of Veterans Affairs that are related to the wars, costs for active-duty service members, Reservists, Guards, and their families who have been using the Department of Defense health care system (TRICARE), including those who are wounded and being treated in military facilities, and costs to the Department of Defense for personnel, retirement, health care, and military replenishment costs related to decisions made during the past decade. $^{12}$

\section{Veterans health care and disability}

Approximately 2.5 million service men and women have served in Operation Iraqi Freedom (OIF), Operation New Dawn (OND), and/or Operation Enduring Freedom (OEF) in Afghanistan to date. There were 6,658 U.S. military fatalities as of 8 March 2013, not including contractors, coalition partners, Afghan and Iraqi partners, and civilians. ${ }^{13}$ By September 2012, some 1.56 million U.S. troops had returned home and left active duty, thereby becoming eligible for veterans medical care and benefits. ${ }^{14}$

Veterans from these wars are utilizing VA medical services and applying for disability benefits at much higher rates than in previous wars. There are two cost streams associated with service-connected veterans: (1) the medical costs of caring for them over their life spans, and (2) the cash compensation and other benefits, such as housing loans and home and physical rehabilitation, that are awarded to eligible veterans and their survivors. In 2008, Stiglitz and Bilmes predicted that costs of both medical care and disability benefits for recent war veterans would grow enormously. We predicted that by 2012 , some 41 to 46 percent of new veterans would be enrolled in the VA health care system, and that 39 to 43 percent would have 
applied for disability benefits. But the original Stiglitz and Bilmes estimates were far too low. ${ }^{15}$ The actual number of Afghanistan and Iraq veterans receiving government medical care has grown to more than 56 percent of the total. One out of every two veterans from Afghanistan and Iraq has already applied for permanent disability benefits. ${ }^{16}$

The costs are high due to the level of physical and mental suffering that has afflicted the troops from these wars. The official number of some 50,000 troops "wounded in action" obscures the scale of the health care situation. One-third of returning veterans are being diagnosed with mental health issues, suffering from anxiety, depression, and/or post-traumatic stress disorder (PTSD). More than 253,000 troops have suffered a traumatic brain injury (TBI) and, in many cases, concurrent with a PTSD diagnosis and complicating treatment and recovery. ${ }^{17}$ The suicide rate in the Army has more than doubled, with many who attempted suicide suffering serious injuries. The mental health epidemic will increase both immediate and long-term costs. In addition to the spending for mental health clinics, hiring psychiatric personnel, and paying higher disability benefits, research from previous wars has shown that these veterans are at higher risk for lifelong medical problems, such as seizures, decline in neurocognitive functioning, dementia, and chronic diseases. $^{18}$

The VA has processed millions of unique application claims but is still facing a substantial backlog. As a result of increases in workload, benefits, and attempts to meet demand, the VA's annual budget has risen, in real terms, from US\$61.4 billion in FY2001 to US\$140.3 billion in FY2013, ${ }^{19}$ growing from 2.5 to 3.5 percent of the total U.S. federal government budget. This reflects huge investments in personnel, clinics, programs, benefits, mental health, IT, women's health care, claims processing, expanded disability pay, and the decision to provide five years of free health care coverage to all newly returned veterans.

\section{Veterans medical costs}

The U.S. has spent US\$23.6 billion during the period FY2001 through FY2013 in providing medical care to OEF/OIF/OND veterans (see Table 1). High medical use is the result of several factors including high survival rates for seriously wounded troops, higher incidence of PTSD and other mental health ailments, more veterans willing to seek treatment for mental health and related problems, and more generous medical benefits, more presumptive conditions, and higher benefits in some categories.

The Veterans Health Administration (VHA) has treated 866,181 (56 percent) of OEF/OIF/OND veterans for a wide range of medical conditions. The most common diagnoses include: Diseases of the musculoskeletal system (principally joint and back disorders), mental health disorders, central nervous system and endocrine system disorders, as well as respiratory, digestive, skin, and hearing disorders. ${ }^{20}$ Of this group, 29 percent have been diagnosed with PTSD. Most veterans have been treated for a variety of different conditions. There is virtually no difference between the former active duty service members and Reservists/Guards, with 56 percent of active duty and 55 percent of Reservist/Guards having obtained VA health care.

The costs of VA medical care include the direct costs of providing care to these individuals, through the extensive network of VA clinics, hospitals, and contract medical support as well as the costs of medical programs that the VA has initiated in recent years in response to specific health concerns from the recent conflicts. These include initiatives for studying, treating, and monitoring PTSD among Afghanistan and Iraq veterans, and spending related to prosthetics for amputees, women veterans' health, and traumatic brain injury (TBI).

The present value of the expected total medical care for OEF/OIF/OND veterans already committed to be delivered over the next forty years is projected to be US\$288 billion. $^{21}$ 


\section{Veterans disability costs}

The U.S. also has spent billions on disability benefits for $\mathrm{OEF} / \mathrm{OIF} / \mathrm{OND}$ veterans. Including the projected costs for FY 2013, the total amount to date will be nearly US\$35 billion (Table 1). The high claims activity is related to better outreach and capacity at the VA, greater availability of information on the internet and through veterans service organizations (VSOs), more conditions that are presumptive in favor of the veteran, and other factors.

As of September 2012, some 783,623 of OEF/OIF/OND veterans ( 50 percent) have filed disability claims with the VA, of whom 671,299 have been awarded service-connection so far, and 15,521 have been denied. (The rest are pending in the VA system). ${ }^{22}$ These applications are complex, with an average claim requesting compensation for eight or more disabling conditions. The complexity of the claims is one of the factors that have led the VA to invest in more personnel and technology to attempt to process the claims more efficiently.

In addition, an estimated US $\$ 4.4$ billion has been paid out to severely disabled veterans through Social Security Disability Insurance (SSDI). More than 30,000 OEF/OIF/OND veterans have been awarded 100 percent service-connection, which makes them automatically eligible to receive supplemental disability compensation from SSDI. ${ }^{23}$ This includes, for example, 6,476 cases of severe penetrating brain injury, and 1,715 individuals with limb amputations. ${ }^{24}$ There are more than 145,000 veterans who are 70 to 90 percent service-connected, many of whom also qualify for SSDI. This would include, for example, some of the 42,063 cases of "moderate" traumatic brain injury.

The present value of the expected total veterans's disability benefits already accrued for OEF/OIF/OND veterans and payable over the next forty years is projected to be US $\$ 424.5$ billion. $^{25}$

\section{Related costs to the Department of Veterans Affairs (VA)}

Certain portions of the cumulative growth of the VA budget (from US\$61 billion in 2001 to US\$140 billion 2013, in constant dollars) are the result of specific decisions, initiatives, programs, benefits, and investments directly related to serving Afghanistan and Iraq veterans. These include expenditures directly related to recent veterans, including readjustment counseling, fast-track processing for OEF/OIF/OND disability claims, hiring of thousands of new mental health professionals to staff clinics for veterans suffering from PTSD, and other items serving the needs of recent veterans. ${ }^{26}$ This also includes expenditures which have been undertaken largely due to the current conflict but which will benefit all veterans. The most costly of these are investments in benefits claims processing,
Table 2: Total projected veterans medical and disability costs (US\$ billions) already spent or accrued (but excluding education benefits)

$\begin{array}{lccc} & \begin{array}{l}\text { Spent } \\ \text { to date }\end{array} & \begin{array}{c}\text { Present value, } \\ \text { 2014-2053 }\end{array} \\ \text { VA medical } & 23.6 & 287.6 & \\ \text { SS disability } & 4.4 & 42.3 & \\ \text { VA disability } & 39.4 & 419.7 & \\ \text { VA related } & 71.5 & 86.6 & \\ \text { Totals } & \underline{134.3} & \underline{836.1} & =\underline{970.4}\end{array}$

Source: Table 1 and author's calculations.

Table 3: Annual growth rate of federal health care programs, 2001-2011

$\begin{array}{lrrr}\text { Medicaid } & 130 & 276 & 7.8 \\ \text { Medicare (net) } & 217 & 485 & 8.4 \\ \text { Veterans medical } & 21 & 50 & 9.1 \\ \text { DoD medical } & 18 & 54 & 11.4 \\ \text { * CAGR=Compound annual growth rate. Source: Congressional } \\ \text { Budget Office, Analysis by Linda Bilmes. }\end{array}$

including automating the disability claims process (which is currently paper-based), and hiring additional personnel to process disability claims. Congress has appropriated this money due to the VA's inability to cope with the huge influx of disability claims from both recent and earlier veterans. ${ }^{27}$ The backlog has been the subject of numerous congressional hearings, Government Accountability Office (GAO) investigations, lawsuits, and media attention. The VA spent US $\$ 1.8$ billion in 2010, US $\$ 2.1$ billion in 2011, US\$2.0 billion in 2012, and US\$2.2 billion in 2013 "to support improved benefits processing though increased staff, improved business processes and information technology enhancements." This spending is in addition to over US $\$ 3.3$ billion per year for each of the past four years "for a reliable and accessible IT infrastructure, a high-performing workforce, and modernized information systems." 28

In total, VA has spent a cumulative sum of US $\$ 71.5$ billion on these war-related initiatives since 2001. Some of the spending will add to the structural base of the VA, particularly the costs related to additional personnel.

Total projected Veterans medical, disability, and related costs The total costs stemming from Afghanistan and Iraq which may therefore be attributed to veterans to date (i.e., year-end 2012) is US $\$ 134.3$ billion (Tables 1 and 2). The present value 
of accrued costs, that is, future medical care and disability benefits already committed but not yet disbursed for $\mathrm{OEF} / \mathrm{OIF} / \mathrm{OND}$ veterans, is estimated at US $\$ 836.1$ billion (Table 2). ${ }^{29}$ This does not include costs associated with the GI Bill, which was enacted in 2008 to provide Afghanistan and Iraq veterans with education benefits on par with those provided to veterans of the second world war. The investment in education for veterans is likely to produce net economic benefits to the nation. It should be noted, however, that the bill will entail budgetary costs, both in direct payments and in administration.

\section{Pentagon medical and personnel costs}

The costs associated with veterans are only a portion of the total accruing medical and personnel costs associated with the Afghan and Iraqi wars. Since 2001, the Pentagon base budget (excluding money appropriated for war spending) has increased cumulatively by more than US $\$ 1.3$ trillion in constant dollars above the levels that were planned prior to $9 / 11$. Much of this increase can be attributed to spending that was related directly or indirectly to Afghanistan, Iraq, and the global war on terror, and much of that is linked to expenditure patterns and decisions regarding personnel levels, pay, and medical care.

\section{Personnel and health care}

The cost of military pay and allowances, along with those for military health care, make up about one-third of the Department's budget and have been rising rapidly in recent years while the total end-strength of active duty service members has barely grown.

Military members and their families are eligible for health coverage through the TRICARE system. TRICARE includes the troops who are injured while serving in the war theater (before they are discharged into the veterans system) and their families. TRICARE spending is likely to reach US $\$ 56$ billion in 2013, up from US $\$ 18$ billion in 2001, accounting for nearly 8 percent of the total U.S. defense budget. TRICARE is now the fastest growing federal health program — growing at a faster rate than Medicare, Medicaid, or VA health care.

There are several reasons why much of this growth can be attributed to the wars in Afghanistan and Iraq. These include (1) increasing participation in TRICARE, (2) increasing utilization of medical services and treatments by TRICARE members, (3) expanding TRICARE to Reservists and Guards, (4) rising profitability of TRICARE companies, and (5) expanding TRICARE programs for retirees.

As to the first of these-increasing participation in TRICARE - the Pentagon has kept the costs associated with

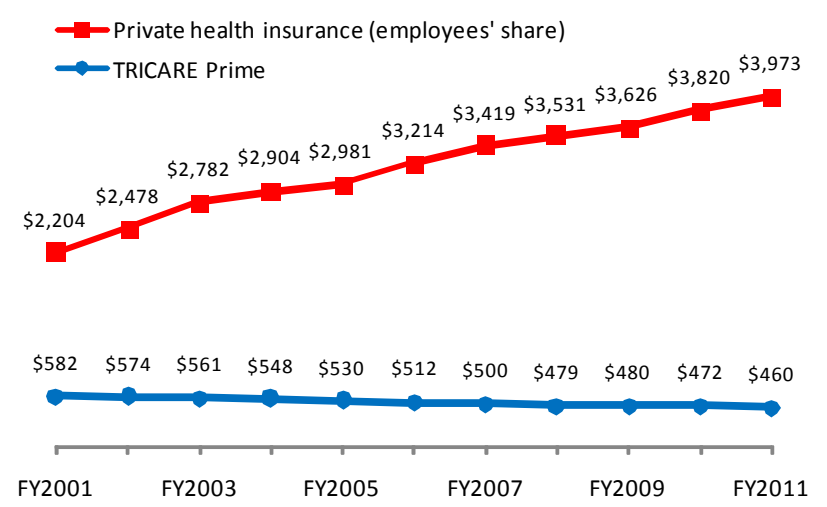

Figure 1: Annual family premiums (in FY2011\$). TRICARE Prime premiums vs. private health insurance premiums, FY2001-FY2011. Source: Employees' share of insurance premium for typical employer-sponsored family health plan: Medical Expenditure Panel Surveys, 2000-2010; forecasted by the Institute for Defense Analysis in FY2011 based on trends in premiums from Kaiser Family Foundation surveys, as of 10 January 2012.

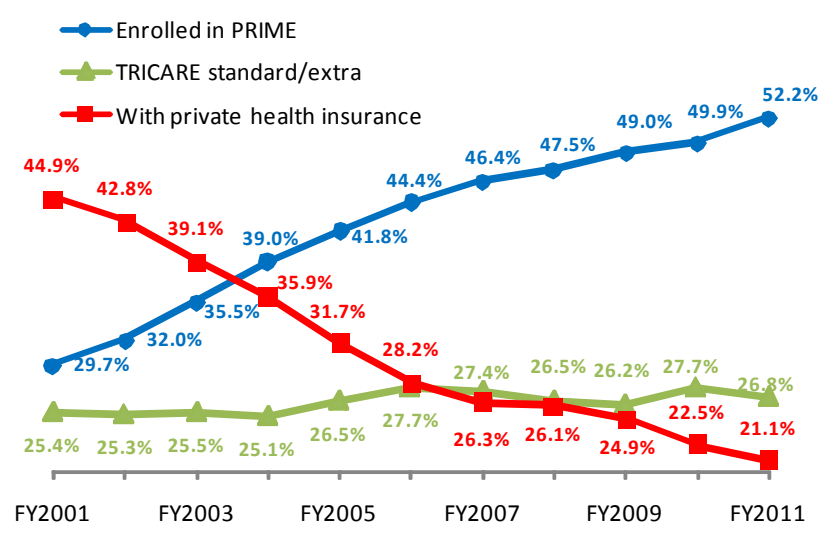

Figure 2: Increased TRICARE and decreased private health insurance coverage, percentage of retiree population $(<65$ years of age) with health insurance coverage, FY2001-FY2011. Sources: DEERS and Health Care Beneficiary Surveys of DoD Beneficiaries, 2001-2011, as of 10 January 2012. Note: The Prime enrollment rates include those who also have private health insurance (about 4 percent of retirees).

TRICARE (co-pays, enrollment fees, deductibles, etc.) artificially low between 2000 and 2012 due to reluctance to raise fees during wartime. Individuals and families can purchase health insurance in TRICARE for a small fraction of the private sector rate. The out-of-pocket amount paid by TRICARE Prime recipients for a family of four actually decreased, in real terms, from US\$582 in 2001 to US\$460 in 2011 (the bottom line in Figure 1). In contrast, during the past decade the market price of health insurance increased steeply (the top line). In fact, the differential between paying for private health coverage compared with TRICARE tripled. 
Consequently, the portion of the total health care costs per individual that TRICARE was subsidizing increased. Unsurprisingly, the participation rate among eligible active duty military and family members rose from 30 to 52 percent, while the percentage that carried private health insurance fell from 45 to 21 percent (Figure 2). ${ }^{30}$ Although there has been a small increase in fees during FY2013, there was substantial congressional opposition to this increase and it is unlikely that fees will go up again anytime in the near future. ${ }^{31}$

Second, regarding increasing utilization of medical services and treatments by TRICARE members, the number of enrollees and the volume of medical visits, procedures, and claims all increased during the period. Overall, TRICARE added 400,000 new beneficiaries between 2004 and 2011, and the number of annual claims processed grew steadily from 112 million in 2004 to 195 million claims in 2011 (Figure 3). ${ }^{32}$ Many of these claims were directly war-related, with much higher utilization by the active duty services and families. For example, since 2004, behavioral health counseling for troops and their families rose by 65 percent and counseling for children of troops rose by 45 percent. Medical visits from active duty troops due to joints and musculoskeletal problems grew from 2.8 million in 2005 to 3.9 million by $2009 .^{33}$

The estimated costs for those who are still serving are large and growing. This includes service members who are wounded on the battlefield and treated within the military medical system, for example, in battlefield medical centers or military hospitals such as the Walter Reed National Military Medical Center (WRNMMC) in Bethesda, Maryland. In 2012 alone, dozens of NATO troops were killed or wounded by members of the Afghan forces (or attackers wearing their uniforms) in so-called green-on-blue attacks. The worst casualties of the entire period occurred during the Afghanistan troop surge. Walter Reed is treating hundreds of recent amputees and severe casualties: The hospital received 100 amputees for treatment during 2010, 170 amputees in 2011, and 107 amputees in 2012. ${ }^{34}$ The Marines have suffered an especially high toll. ${ }^{35}$

Third, TRICARE was expanded to the Guards and Reserves who had served in the wars, establishing a new program called TRICARE Reserve Select (TRS). This was a direct response to the fact that a large percentage of those who have served in OEF/OIF/OND have been drawn from Reservists and Guards. Of those who have already been discharged, 43 percent $(674,688)$ are Reservists/Guards and 882,338 (57 percent) are active duty. ${ }^{36}$ The TRS program was originally designed for Reservists and Guards who lacked a civilian option, but it has become a default plan for many. The participation rate (and the cost) is likely to increase further when the mandates in the Affordable Care Act take effect.

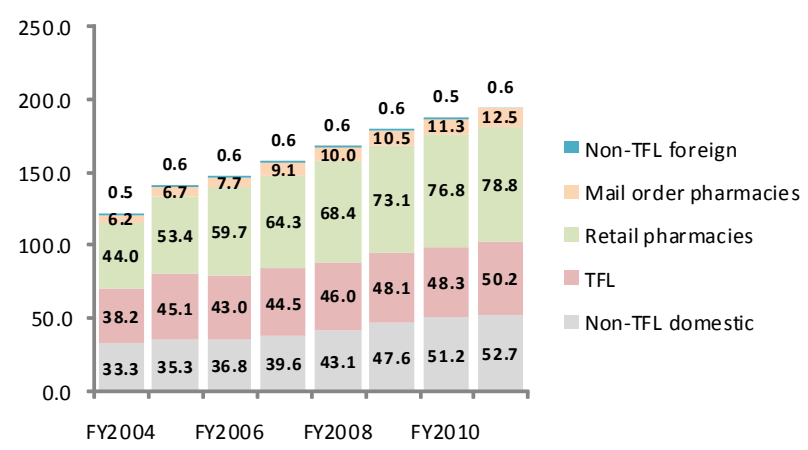

Figure 3: Number of TRICARE claims processed (in millions), FY2004-FY2011. Note: TFL=TRICARE for Life program. Foreign claims are excluded. Source: MHS administrative data (as of 20 November 2011).

RAND Corporation recently projected that this program will grow significantly in 2013 and 2014, as TRS will become by far the cheapest option for those able to take advantage of it. Currently, some 30 percent of Reservists and Guards are not insured. TRS premiums will be less expensive for these individuals than purchasing health insurance in the private market, through state subsidized health exchanges, or paying a penalty for not having insurance. ${ }^{37}$

Fourth, the private sector health insurance companies that comprise TRICARE have proven to be major beneficiaries of the largesse in military expenditure over the past decade, experiencing large increases in enrollments, revenues, and profits. Taken together, the three companies that have administered TRICARE (Humana, Health Net, and TriWest Health Care $)^{38}$ would rank as the 6th largest contractor for the Department of Defense - bigger than KBR, and just below the biggest contracting names such as Lockheed, Northrup Grumman, and Boeing. These firms account for some of the highest profits earned by any company in the war. For example, Humana's TRICARE Premium fee revenues increased from US $\$ 2.8$ billion to US $\$ 4.2$ billion between 2001 and 2010, as the company shifted a larger percent of its operations into the government sector. ${ }^{39}$

This situation is hardly surprising, considering that Congress was appropriating gigantic sums to the Department of Defense for the war, through so-called emergency funds, which have little oversight. The TRICARE providers had no incentive to contain costs. The DoD was mostly concerned with the availability and quality of medical care for its troops and reimbursed whatever was requested. The TRICARE beneficiaries, with heavily subsidized co-pays, also have no incentive to economize. An analysis conducted by TRICARE shows that recipients have 30 to 40 percent higher medical utilization rates than civilians and use 30 percent more 
prescriptions per year than civilian HMO users (Figure 4). ${ }^{40}$

Finally, fifth, the Pentagon expanded benefits for military retirees, in part because the wartime appropriations climate helped the department persuade Congress to agree to a number of longstanding requests. These included adding "concurrent receipt," an expensive benefit that permitted working-age military retirees who also qualify for VA disability benefits to accept both.

TRICARE also expanded the TRICARE for Life (TFL) program, enacted in 2001, to augment Medicare for military retirees over age 65 and their families. Military service members are eligible to retire after 20 years, and TFL is a popular benefit that has grown rapidly. Unlike Medicare, TRICARE can negotiate for higher rates to pay its providers (regardless of Medicare rates), so there is less likelihood that providers will choose not to accept TFL patients. Like other TRICARE fees, the enrollment fees for TFL are low and it provides additional security for retired military service members and their families.

These decisions will increase the base Pentagon budget permanently and it will continue to grow quickly as the demographics of the population shift more people into these categories. While neither of these decisions was a direct cost of the war, both should rightly be considered as indirect costs. The scale of war appropriations, combined with the desire to improve benefits for the all-volunteer force, created an environment in which it was possible for DoD to enact concurrent-receipt, which it had been advocating for decades. The launch of TFL and its heavily subsidized prices was also made easier by the wartime environment.

In sum, while the Pentagon budget is projected to decrease over the next decade - and assuming the continuation of the sequestration path that went into effect in 2013, the total DoD budget decreases even further-the growth of TRICARE will significantly eat into the base budget. TRICARE presently consumes 8 percent of the defense budget; if it continues to grow at the current rate, it will consume 18 percent of the total DoD budget by 2017, and the core DoD budget not related to medical costs will shrink from 16 percent of total U.S. budget outlays to 10 percent (Figure 5).

\section{Personnel costs}

The second main area of increased military base cost is in pay and benefits. When the Army and the Marines faced recruiting difficulties in 2004, the Pentagon made a number of changes to boost recruiting to the all-volunteer force. These included relaxing some standards for education and fitness

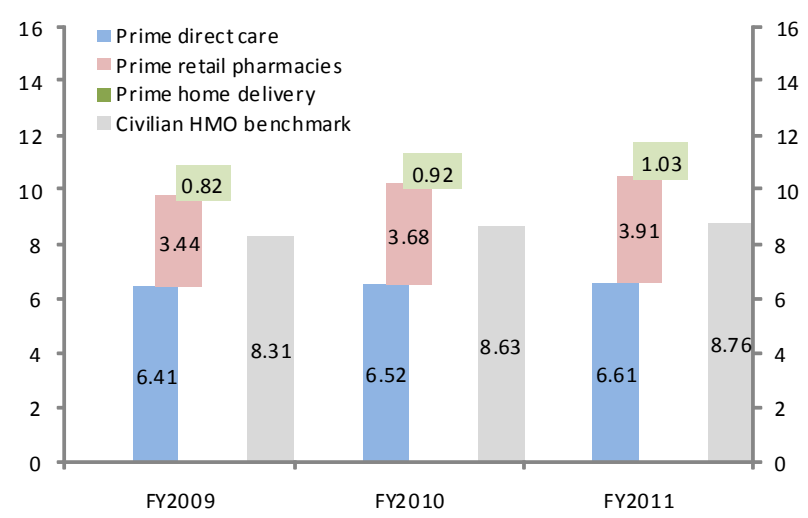

Figure 4: Prescription utilization rates (in percent) by source of care: TRICARE Prime vs. civilian HMO benchmark. Sources: MHS administrative data, 30 January 2012, and Thomson/Reuters, Inc., MarketScan Commercial Claims and Encounters Database, 12 December 2011. Note: The civilian data for each year were adjusted to reflect the age/sex distribution of the MHS beneficiary population. FY2011 civilian data are based on two quarters of data, which were seasonally adjusted and annualized. (1) Source of care (direct or purchased) is based solely on where care is received, not where beneficiaries are enrolled.

among recruits, increasing the number of recruiters, and increasing pay. Congress authorized pay raises above Pentagon request levels.

A key decision was to adopt higher pay scale indexing. Previously, pay increases were linked to the employment cost index (ECI). The new method was to link pay scales to the ECI plus 0.5 percent. This pay enhancement tool was made possible by the overall surge in war spending, but it was not funded through wartime appropriations and it has added another layer of cost to the DoD base. In the FY2012 and FY2013 budget requests, DoD has asked Congress to roll back these benefits, but they are politically untouchable.

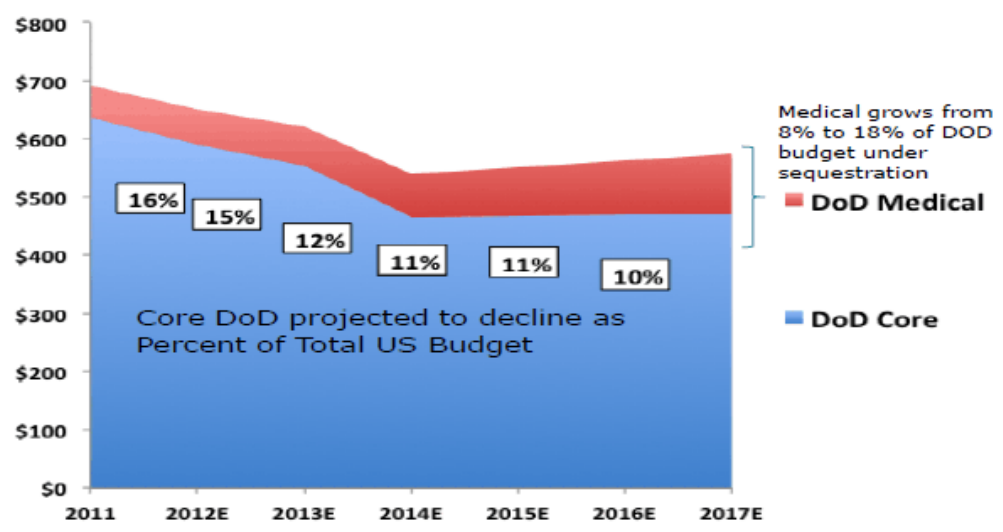

Figure 5: Potential growth of DoD medical costs vs. base (US\$ billions). 
Another important cost was activating Reservists and Guards and paying them on a full-time basis. ${ }^{41}$ This was an extra, incremental expense. In total, more than 670,000 Reservists and Guards have been deployed in the Afghan and Iraqi wars. In addition, these troops were on average five years older and with families, so they were in most cases entitled to receive higher levels of special adjustment pay, combat pay, and parental and other benefits.

One significant personnel cost that is likely to grow in the future as a consequence of the wars is the military retirement pension system. The United States now pays over US $\$ 100$ billion annually in generous military retirement benefits for those who have served for at least 20 years. There is no pension at all for those who have served for fewer than 20 years. In the Afghan and Iraq conflicts, more than 85 percent of the troops, including nearly all the front-line infantry troops, have not served for that long. ${ }^{42}$ Therefore they are not eligible to receive any kind of pension or stipend for their service. The current all-or-nothing system was designed after the second world war and is ill-suited to today's veterans in the all-volunteer force. Many respected military analysts, including Lawrence Korb of the Center for American Progress, have pointed out that it makes little sense to design a system that fails to compensate more than 80 percent of those who fight.

One short-term result of this inequity is that it has placed additional pressure on the veterans' disability benefit system which, in effect, provides a small supplementary income for many returning troops. Many Afghanistan and Iraq veterans have given up several years of their lives, spent time away from their families, sustained minor to moderate injuries, and suffered from quality of life impairment in a number of ways. However, unlike the British and Australian approach, neither the military pension system nor the veterans system in the U.S. compensates for lower quality of life. ${ }^{43}$ It is therefore plausible to believe that the veterans' disability benefit has become in some cases a proxy for such compensation, and that some veterans apply for multiple disability benefits to secure some level of permanent income supplement.

The majority of these costly measures-including supplementary pay increases, expansion of TRICARE subsidies, upgrades to the VA system, and increases in eligibility for veterans benefits-were adopted, at least in part, because the U.S. was facing the first big test of the all-volunteer force (AVF). The AVF depends on a pipeline of recruits, and research has shown that the recruiting pool to the AVF is sensitive to economic inducements, including veterans' benefits. ${ }^{44}$ But from a budgetary standpoint, these have been hidden costs of the war, in which cumulatively hundreds of billions of dollars have been spent on expanding military health care, pay, recruitment, and service and retirement benefits, without any discussion about how to pay for them. Most of these costs were not covered by war appropriations. And when the topic of pensions is examined in the coming years, it is likely that any reforms that benefit the current generation of veterans will require additional long-term expenditures for the defense department.

\section{Other defense department costs}

\section{Military reset}

Throughout the war effort, the Pentagon's base budget has been padded with war expenditures. At the same time, the war budget has funded many items that should have been paid for through the regular budget. It is difficult to disentangle these two streams, particularly due to the use of emergency supplemental funding throughout most of the conflict. This funding mechanism is supposed to be reserved for genuine emergencies, such as hurricanes and earthquakes, where the priority is to get the money spent quickly. The requirements for vetting emergency budget requests are much less stringent than for normal budgets, and the spending is outside the regular spending caps imposed by the budget. In the period from FY2001 to FY2010, Congress enacted more than 30 such emergency bills to fund the war, a strategy that has been widely criticized by the Government Accountability Office (GAO), the Congressional Research Service (CRS), the Congressional Budget Office (CBO), and others. Accordingly, the requests received minimal scrutiny and the DoD was able to push through hundreds of billions of dollars in spending items that were not directly related to the war effort as part of the emergency supplemental process.

The CRS and CBO have found it difficult to untangle this record. Certainly, some funds have been appropriated for specific war replacements, such as US\$3.1 billion to upgrade 23,000 MRAP vehicles. But CBO found that more than 40 percent of the Army's spending for "reset" (the repair and replacement of war-worn equipment) was not spent on replacing lost equipment or repairing equipment sent home. Instead, these funds went "to upgrade systems, to increase capability, to buy equipment to eliminate longstanding shortfalls in inventory, to convert new units to modular configuration, and to replace equipment stored overseas for contingencies." It is unclear, the CBO stated, how much of this reflected stress on equipment from war operations as opposed to the Department's longstanding wishes to upgrade in these areas.

CRS has reported that much of this equipment was originally slated for repair at a later date, so is being repaired sooner than anticipated. ${ }^{45}$ In theory, this would suggest that the 
U.S. taxpayer could expect to see a reduction in the regular defense budget to offset the repairs inappropriately allocated to the wars. But the accounting systems at the Pentagon are so inadequate that it is not feasible to pin this down with any degree of accuracy. It seems more likely that the strain of the war has led to a vast understatement of the depreciation of equipment and weaponry. In part, this is due to the wartime decision to use sometimes dubious local contractors to repair and maintain much of the equipment during the war period, many of whom had little training in the maintenance of such equipment.

There will be a large price tag for simply deciding what to leave, destroy, or bring home. Other large price tags will include (1) transporting equipment, troops, and weapons home from Afghanistan, (2) replacing, modernizing, and replenishing equipment, and (3) replacing, modernizing, and replenishing National Guard equipment which has been heavily used during the past decade.

In this analysis, some US\$750 billion of this increase has been attributed to the total indirect costs of the Afghan and Iraqi operations, which includes (1) health care costs, (2) personnel, (3) recruitment, (4) overheads related to the procurement, monitoring, legal, evaluation, and other costs related to these programs, (5) and depreciation of ordinary equipment that has been damaged, or consumed, during the wars more rapidly than its peacetime life rate, or that is too expensive to bring back home. This depreciation has not been adequately accounted for in the war appropriations and should in most part be attributed to the original budget through which most of these items were purchased. There are maintenance, repairs, and upgrades charges beyond those included in war appropriations, particularly for helicopters, fixed wing aircraft, light vehicles, and trucks, which have been consumed at several times the peacetime rate. This amount is consistent with other estimates, some of which have been prepared using a different approach. ${ }^{46}$

\section{Ongoing commitments}

As of March 2013, there were still more than 60,000 U.S. troops stationed in Afghanistan who will incur operational costs until their withdrawal (scheduled by 2014) and will likely incur many of the medical and disability costs described earlier.

There are also substantial future costs stemming from the commitments the U.S. has made in the region. The U.S. is maintaining a vast diplomatic presence in Iraq and at least 10,000 private contractors providing support in security, IT, logistics, engineering, and other occupations, as well as logistics support and payments for leased facilities in Kuwait.
The U.S. has made extensive commitments to Afghanistan beyond combat. In 2012, President Obama signed an agreement with Afghan President Hamid Karzai, called the Enduring Strategic Partnership Agreement between Afghanistan and the United States, or SPA for short. ${ }^{47}$ The SPA is a legally binding executive agreement that runs through 2024. It states that we "commit ourselves to the sovereignty, independence, territorial integrity and national unity of Afghanistan. The Agreement is not only a signal of the United States' long-term commitment to Afghanistan, but it enshrines our commitments to one another and a common vision for our relationship and Afghanistan's future. U.S. commitments to support Afghanistan's social and economic development, security, institutions and regional cooperation are matched by Afghan commitments to strengthen accountability, transparency, oversight, and to protect the human rights of all Afghans-men and women. ${ }^{.48}$

Given that Afghanistan is one of the poorest countries in the world, it is widely expected that the U.S. will continue to pay for the upkeep of the army and police force in that country for the foreseeable future. There are many unknowns, for example, whether the nearly 2 million Iraqi refugees who resettled in Syria during the Iraq conflict, and who are now caught up in the Syrian conflict, will require long-term humanitarian or other assistance that will impose additional costs on the United States. Meanwhile, Iraq is still violent and is aligning more closely with Iran. None of these costs, of course, takes into account the human costs of the wars for all the nations involved, which may be impossible to quantify.

\section{Impact of borrowing for the wars}

The U.S. has already borrowed some US $\$ 2$ trillion to finance the Afghan and Iraqi wars and the associated defense build-up, a major component of the US\$9 trillion U.S. debt accrued since 2001.

Studies of the budgetary impact of wars funded largely by borrowing naturally focus on the interest costs: Anyone who buys a house or car on credit knows that the interest payments may easily be far larger than the purchase price. But critics say that to include the interest costs is double-counting, and that one should simply determine the (expected) present discounted value of the payments. In previous writings, Stiglitz and Bilmes have argued that if it were costless to raise money, then imposing future costs on the budget through borrowing (necessitating raising more tax revenues in the future) would be of no concern. The timing of financing would be irrelevant. But in reality the costs can be substantial, so that there is a distortionary cost associated with these future budgetary payments. The magnitude of these costs depends on the 
magnitude of the distortions associated with a country's tax system. ${ }^{49}$ Additionally, the majority of funding for these wars has been from foreign, not domestic lenders.

Therefore it is legitimate to consider the impact of borrowing for these wars. The immediate budgetary cost has been US\$260 billion in interest paid for borrowings to date. There are two future costs: Interest accrued but not yet paid on current borrowings, and interest on future borrowings (much of which will be used to service current debt). The potential interest cost of the U.S. war debt reaches into the trillions. But of greater consequence is the fact that we deliberately chose to finance the wars in this fashion, passing on the costs to future generations. As Robert Hormats, the former Vice Chairman of Goldman Sachs, has pointed out, it is unprecedented in U.S. history that we pay for a war entirely from debt, and actually cut taxes repeatedly during wartime (as done in 2001 and 2003). ${ }^{50}$ The only previous episode that is at all comparable occurred during the Revolutionary War, when the U.S. colonies borrowed from France.

It is important to note that this borrowing has not been used to invest in the country's capital stock. For example, investing in education, infrastructure, and knowledge benefits the nation, so this is debt for a helpful purpose. By contrast, the war debt has been especially unhelpful. Large amounts have been spent on things that clearly did not benefit the United States-for example, US\$87 billion in reconstruction funding for Afghanistan, and US\$61 billion in Iraq, much of which has been squandered according to the Special Inspector General for Afghanistan Reconstruction (SIGAR) and Iraq Reconstruction (SIGIR), respectively. Moreover, the war spending diverted resources that might otherwise have been available to help stimulate the economy during 2008-2009, when the U.S. endured the worst economic collapse since the Great Depression. $^{51}$

In addition to the future costs associated with veterans described in this article, we have therefore saddled the nation with the debt for the operational costs of the wars. Already, the national debate over the debt has influenced policy decisions. Despite widespread unhappiness with the sequester mechanism, Congress allowed these across-the-board cuts in the discretionary budget, including the defense and state departments. These cuts are likely to have wide-ranging effects, including cuts to defense-related R\&D programs at universities and programs that facilitate a pipeline of recruits into the national security agencies, such as summer internships for students in embassies worldwide. Many in Washington support drastic cutbacks to entitlement programs and other measures in order to reduce the long-term debt obligations of the U.S. government.

\section{Conclusions}

By the most conservative reckoning, the Afghan and Iraqi conflicts will cost US\$4 trillion, including operations through year-end 2012, accrued veterans medical and disability costs, indirect costs to the Department of Defense, social costs for veterans' families, and interest already paid. Any estimation of macroeconomic costs, such as the impact of higher oil prices on weakening aggregate demand, and the link between oil prices and decisions of the Federal Reserve Bank to loosen monetary and regulatory policy prior to the financial crisis, would easily raise the cost to US\$5 or US\$6 trillion, even if only a fraction of the "blame" is attributed to the wars. ${ }^{52}$ Throughout the past decade, the United States has underestimated the length, difficulty, cost, and economic consequences of these wars, and it has failed to plan how to pay for them.

What did the country buy for US\$4 (or more) trillion? The U.S. still faces a perilous international security situation and a fragile economy. Today, as the country considers how to improve its balance sheet, it could have been hoped that the ending of the wars would provide a peace dividend, such as the one during the Clinton administration that helped U.S. Americans to invest more in butter and less in guns. Instead, the legacy of decisions made during the Afghan and Iraqi conflicts will impose significant long-term costs on the federal government and, in particular, on the consolidated national security budget. ${ }^{53}$ These decisions extend far beyond the initial choices made to invade Afghanistan, to invade Iraq, and to expand U.S. military involvement in both countries. They include the decisions to expand medical care and disability benefits for war veterans, to grow the Department of Defense medical system, to increase military pay, to mobilize the Guards and Reserves, to deploy and use up large quantities of basic equipment, to support an ongoing diplomatic presence and provide military assistance in the region, and to finance the wars with debt.

The U.S. military is reeling under the large and rapidly-growing cost of the TRICARE health care system, the supplementary military pay raises enacted during the war years, and the diversion of defense budget dollars to support the requirements of veterans, which will dominate future defense spending. These commitments have already cost on the order of US\$700 to US\$800 billion, and are set to continue, unless there is a significant reversal of current policies. The base VA budget has nearly tripled during the period, with much of this growth now "baked in" to the consolidated national security budget.

Assuming that this pattern continues, there will be a much smaller amount of an already-shrinking defense budget 
available for core military functions. There will also be less available for urgent but overlooked needs, including investing more in the human capital of diplomacy, improving accounting and budgeting systems at DoD, green initiatives (when the Pentagon has pioneered efforts to become more energy efficient), and training and education for civilians.

The United States will face difficult trade-offs in funding these long-term obligations as well as military operations, new initiatives, research, development, and diplomacy. The national security agencies, the budgets of which already are scheduled to decrease, will come under more pressure. One likely result is that the budgetary constraints will tilt the U.S. in a direction of fewer military personnel in the forces, due to the immediate and long-term cost of maintaining active-duty end-strength. Instead of end-strength, budget considerations will favor greater investment in unmanned weaponry, robotics, and other technological solutions, which may or may not be a wise choice over the longer-term.

In short, there will be no peace dividend, and the legacy of the Afghan and Iraqi wars will be costs that persist for decades.

\section{Notes}

1. A version of this article was first presented at the ASSA meetings in January 2013. A revised version was published in the Harvard Kennedy School Faculty Research Working Paper Series (RWP13-006) in March 2013.

2. Joseph E. Stiglitz and Linda J. Bilmes have written extensively on the long-term costs of war. See Stiglitz and Bilmes (2008) and Bilmes and Stiglitz (2011; 2012).

3. Belasco (2009) estimates US\$1.4 trillion through 2012. (The US\$2 trillion figure is updated for 2012-2013 expenditures, including additional VA, DoD, Social Security spending and interest paid on money borrowed for the wars.)

4. Edwards (2010a; 2010b). See also Institute of Medicine publications on long-term disability costs, including NRC (2010).

\section{VBA (2012).}

6. The most significant cost that is associated in economics with lives lost is the VSL. There is a large literature of estimating this value. Government agencies routinely use estimates of the VSL in making decisions, such as weighing the costs and benefits of car or drug safety regulations. The Environmental Protection Agency estimates the VSL at US\$6.9 to US\$8.7 million. We have used the figure of US\$7.2 million, which is the mid-range of numbers used by government agencies. Stiglitz and Bilmes (2008) and Viscusi and Aldy (2003).

\section{See Stiglitz and Bilmes (2008).}

8. See interviews with then-Secretary Donald Rumsfeld (10 March 2005) in which he estimated that U.S. military equipment such as tanks, Bradley fighting vehicles, and helicopters were being worn out at up to six times the peacetime rate. Also, see interview with then-Deputy Secretary of Defense Ashton Carter (11 July 2012) describing challenges of dismantling 400 bases and transporting 45,000 military vehicles, including 14,000 Mine Resistant Ambush Protected (MRAP) trucks, back from Afghanistan in difficult terrain.

9. President Obama and President Hamid Karzai signed a Strategic Partnership Agreement in May, 2012 that commits the U.S. to assist Afghanistan with security through 2024. Most estimates place the financial obligation in the range of US\$8 to US $\$ 10$ billion annually. See endnote 48 .

10. Between 30 September 2001 and 30 September 2012, the total U.S. debt grew from US\$5.8 trillion to US\$16.0 trillion (U.S. Treasury). According to Edwards (2011), post-9/11 war spending has increased indebtedness by US $\$ 1.3$ trillion, raised the ratio of public debt to GDP by 9 to 10 percentage points, and probably raised long-term interest rates by 30 to 35 basis points.

11. Edwards (2011; updated March 2013). The total interest on the war debt could reach US\$7 trillion, dwarfing all other costs, depending on interest rates, GDP, and the level of future borrowing.

12. This article does not update the macroeconomic analysis developed with Joseph E. Stiglitz previously. See Stiglitz and Bilmes (2008) and Bilmes and Stiglitz (2011; 2012).

13. Department of Defense casualty status data as of 8 March 2013. The organization "icasualties" estimates 8,074 total U.S., U.K., and coalition fatalities since 2001. According to U.S. Government Accountability Office (GAO) reports in 2010, at least 455 U.S. contractors have been killed and 15,000 injured. This is likely to be an underestimate. These may show up as additional costs to Medicare and the U.S. health care system, but are not included in this study.

14. Veterans' medical care is appropriated through the discretionary budget in the Veterans Health Administration (VHA). Once granted, disability benefits are a mandatory authorized entitlement and are administered by the Veterans Benefit Administration (VBA). Some benefits are payable to all veterans regardless of their disability status, including five years of free medical care in the veterans health care system upon their discharge from active duty. Veterans can qualify for a range of compensatory benefits and stipends on approval from the medical and administrative apparatus of the VA. Additionally, veterans may be eligible to receive assistance from other government agencies, such as supplementary disability compensation from the Social Security Administration if they can no longer work.

15. In previous analyses we based the estimates on two scenarios, a best-case scenario and a moderate-realistic scenario. The actual level of medical utilization and disability claims has far exceeded the higher of our estimates.

16. VBA (2012).

17. Fischer (2013). 
18. See Hoge, et al. (2002). See also work from the Veterans Health Research Institute, Cohen, et al. (2009), Boscarino (2008), Boscarino, Forsberg, and Goldberg (2010). The latter study, a study of twin pairs, showed that the highest PTSD sufferers were 3.8 times more likely to have rheumatoid arthritis compared with the lowest sufferers. In addition, see Andersen, et al. (2010).

19. See Table 1 in Scott (2012) and "Department of Veterans Affairs FY2013 President's Budget,” 13 February 2013.

20. "Analysis of VA Health Care Utilization among Operation Enduring Freedom (OEF), Operation Iraqi Freedom (OIF) and Operation New Dawn (OND) Veterans" (October 1, 2001 to September 30, 2012). Epidemiology Program. Veterans Health Administration. Department of Veterans Affairs (January 2013).

21. The costs described here include the cost of veterans based on administrative records obtained from the VA. It does not include Vet Center data, which would increase the numbers if we had it. The evidence from previous wars shows that the cost of caring for war veterans rises dramatically over time as veterans get older and their medical needs grow. This does not include the cost of veterans beyond age 67, who will also be covered through Medicare, TRICARE for Life, and other systems.

22. VBA (2012).

23. VBA (2012). Social Security provides disability compensation for individuals who cannot work due to disability. Veterans can receive both VA disability compensation and SSDI. Veterans who are service-connected at the 100 percent level automatically qualify for SSDI. Most veterans who are 90 percent service-connected, and many who are 70 to 80 percent would also qualify for this compensation.

24. Fischer (2013).

25. This does not include veterans' education benefits under the GI Bill.

26. These are discussed in detail in the FY2009 through FY2013 VA budgets, and summarized in the "VA Budget Fast Facts" issued with the budget each fiscal year.

27. It is reasonable to attribute this spending to the Afghan and Iraq wars, which have produced a huge upsurge in the number and complexity of disability claims. The VA has expanded eligibility, granted more presumptions to the veteran, increased outreach, liberalized the PTSD stressor definition, and consequently, it has received more than 1 million claims per year during each of the past three years, from all veterans, 2010, 2011, and 2012. If not for the outcry among veterans, and the congressional and public support for them, it is unlikely that the VA would have been able to secure appropriations for this amount of funding at a time of rising deficits and austerity in most of government. These estimates do not include VA capital investments, such as the construction that will serve all veterans, but are primarily targeted toward those returning from Afghanistan and Iraq.

\section{See VA Budget Fast Facts, FY2009-FY2013.}

29. This figure is not estimated in government accounting. The U.S. consolidated balance sheet lists US\$1.3 trillion in liabilities for veterans' compensation and burial benefits (for all veterans) but does not include medical care or pensions in its listing of liabilities. The Congressional Budget Office (CBO) typically projects forward only ten years, with focus on the near-term. In October 2010, CBO estimated that the cumulative health care costs for Afghanistan and Iraq veterans for the years 2011-2020 will be US\$40 billion to US\$54 billion and will rise steeply as the veterans get older. These estimates are consistent with the projections in this article. However, CBO does not include the cost of disability benefits, Social Security disability, or other VA costs. The actuarial capability of the VA is weak and has been the focus of criticism by the GAO and the Institute of Medicine. In 2009 GAO found that VA's assumptions of the costs of long-term care were "unreliable" because the assumed cost increases were lower than VA's actual spending experience. See GAO-09-664T.

30. "Evaluation of the TRICARE Program: Access, Cost and Quality." FY2012 Report to Congress. Washington, D.C.: U.S. Department of Defense.

31. As of 1 October 2012, TRICARE Prime enrollment fees for uniformed service retirees and families rose from US\$230 to US\$260 (individual) to US\$269.28 and from US\$460 to US\$520 (families) to US\$538.56.

32. Military Health Service, TRICARE 2012.

33. Military Health Service, TRICARE 2012.

34. Data from TRAC2ES as of 28 February 2010, WRNMMC.

35. For example, 25 Marines died and more than 180 were wounded, including many with multiple amputations, from a single battalion in the Fifth Marine Regiment out of Camp Pendleton, California, while it was deployed to Helmand Province in 2010.

36. "Analysis of VA Health Care Utilization Among OEF/OIF/OND Veterans." http://www.publichealth.va.gov/ docs/epidemiology/healthcare-utilization-report-fy2012-qtr4. pdf. Released January 2013. Epidemiology Program, Post-Deployment Health Group, VHA.

37. See Hose (2012).

38. In 2012, TRICARE decided to shift its US\$20.5 billion contract for western states from TriWest to UnitedHealth Group Inc. (UNH), the nation's largest health insurer by revenue. This will take effect starting 1 April 2013.

39. See company filings at EDGAR, the Security and Exchange Commission's (SEC) online company database.

40. Military Health Service, TRICARE 2012.

41. Reservists and Guards typically are paid for one weekend per month plus special training sessions. Service in the National Guards is paid by the states. If the Guard is called up by the Governor of that state, the state pays. The federal government pays 
only if the Guard is called to active national duty, as was the case for Guards who were called to serve in Afghanistan and Iraq.

42. Korb, Rothman, and Hoffman (2012).

43. Some countries, including Australia, Britain, Canada, and New Zealand pay lump-sum quality-of-life impairment stipends to veterans who suffer injuries.

44. Simon and Warner (2007).

45. See CBO (2009); for CRS, see Belasco (2009, pp. 27-30). 46. Winslow Wheeler (2011) estimates that US\$720 billion in non-war Pentagon base cost increases should be attributed indirectly to the cost of the conflict: www.costsofwar.org (Brown University study, 2013).

47. The full text of the agreement is available at http://www.whitehouse.gov/sites/default/files/2012.06.01 u.s.-afghanistanspasignedtext.pdf.

48. President Obama and President Hamid Karzai signed the agreement in May 2012. It commits the U.S. to assist Afghanistan with security through 2024. Most estimates place the financial obligation in the range of US\$8 to US\$10 billion annually. A copy of the actual agreement is available at http://photos.state.gov/libraries/afghanistan/231771/PDFs/20 12-05-01-scan-of-spa-english.pdf. A Congressional Research Service paper on the long-term costs of continuing assistance to Afghanistan is available at https:/www.fas.org/sgp/crs/row/ RL30588.pdf.

49. Bilmes and Stiglitz (2011).

50. Hormats (2007).

51. Joseph Stiglitz was one of many economists who said that the American Reconstruction and Recovery Act should have been bigger in order to help stimulate growth and employment in the U.S. One of the reasons the administration was not able to increase the package was due to the financial constraints imposed by war spending.

52. Oil prices increased from US\$23 per barrel prior to the invasion of Iraq to a peak of US\$140 in 2008 and since then have stabilized at around US\$100 per barrel. On the macroeconomic impact of this and other war costs, see Stiglitz and Bilmes (2008) and Bilmes and Stiglitz (2012).

53. That is, the Pentagon, VA, State, and related budgets.

\section{References}

Andersen, J. et al. 2010. “Association Between Posttraumatic Stress Disorder and Primary Care Provider-Diagnosed Disease Among Iraq and Afghanistan Veterans." Psychosomatic Medicine. Vol. 72, No. 5, pp. 498-504. http://dx.doi.org/10.1097/PSY.0b013e3181d969a1

Belasco, A. 2009. "The Cost of Iraq, Afghanistan, and Other Global War on Terror Operations since 9/11." CRS Report RL33110. Washington, D.C.: Congressional Research Service.

Bilmes, L.J. and J.E. Stiglitz. 2011. "The Long-term Costs of
Conflict: The Case the Iraq War," in D.L. Braddon and K. Hartley, eds. The Handbook on the Economics of Conflict. Cheltenham, UK: Elgar. http://dx.doi.org/10.4337/9780857930347.00017

Bilmes, L.J. and J.E. Stiglitz. 2012.."Estimating the Costs of War: Methodological Issues, with Applications to Iraq and Afghanistan," in M. Garfinkel and S. Skaperdas, eds. The Oxford Handbook of the Economics of Peace and Conflict. New York: Oxford University Press.

Boscarino, J.A. 2008. "A Prospective Study of PTSD and Early-Age Heart Disease Mortality Among Vietnam Veterans: Implications for Surveillance and Prevention." Psychosomatic Medicine. Vol. 70, No. 6, pp. 668-676. http://dx.doi.org/10.1097/PSY.0b013e31817bccaf

Boscarino, J.A., C.W. Forsberg, and J. Goldberg. 2010. “A Twin Study of the Association Between PTSD Symptoms and Rheumatoid Arthritis." Psychosomatic Medicine. Vol. 72, No. 5, pp. 481-486. http://dx.doi.org/10.1097/PSY.0b013e3181d9a80c

Cohen, B.E., C. Marmar, L. Ren, D. Bertenthal, and K.H. Seal. 2009. "Association of Cardiovascular Risk Factors with Mental Health Diagnoses in Iraq and Afghanistan War Veterans Using VA Health Care." Journal of the American Medical Association. Vol. 302, No. 5, pp. 489-492. http://dx.doi.org/10.1001/jama.2009.1084

Edwards, R.D. 2010a. "U.S. War Costs: Two Parts Temporary, One Part Permanent.” NBER Working Paper 16108. Cambridge, MA: National Bureau of Economic Research.

Edwards, R.D. 2010b. "A Review of War Costs in Iraq and Afghanistan.” NBER Working Paper 16163. Cambridge, MA: National Bureau of Economic Research.

Edwards, R.D. 2011. "Post-9/11 War Spending, Debt, and the Macroeconomy." 22 June 2011. Cost of War Project. Watson Institute. Brown University. Providence, RI: Brown University.

Fischer, H. 2013. "U.S Military Casualty Statistics: Operation New Dawn, Operation Iraqi Freedom, and Operation Enduring Freedom." Congressional Research Service Report RS22452 (5 February 2013). Washington, D.C.: Congressional Research Service.

Hoge, C.W. et al. 2002. "Mental Disorders Among US Military Personnel in the 1990s: Association with High Levels of Health Care Utilization and Early Military Attrition." American Journal of Psychiatry. Vol. 159, No. 9, pp. 1576-1583. http://dx.doi.org/10.1176/appi.ajp.159.9.1576

Hormats, R.D. 2007. The Price of Liberty: Paying for America's Wars. New York: Time Books, Henry Holt and Company.

Hose, S.D. 2010. Healthcare Coverage and Disability Evaluation for Reserve Component Personnel: Research for the 11th Quadrennial Review of Military Compensation. Santa Monica, CA: RAND Corporation. http:/www.rand. org/pubs/monographs/MG1157.

Korb, L.J., A. Rothman, and M. Hoffman. 2012. "Reforming

The Economics of Peace and Security Journal — ISSN 1749-852X — http://www.epsjournal.org.uk (C) EPS Publishing, 2014. All rights reserved. For permissions, email: ManagingEditor@epsjournal.org.uk 
Military Compensation: Addressing Runaway Personnel Costs Is a National Imperative.” 7 May 2012. Washington, D.C.: Center for American Progress.

[NRC] National Research Council. 2010. Returning Home from Iraq and Afghanistan: Preliminary Assessment of Readjustment Needs of Veterans, Service Members, and Their Families. Washington, D.C.: The National Academies Press.

Scott, C. 2012. "Historical Budget Authority for the Department of Veterans Affairs in Constant 2011 Dollars, FY1940-FY2012." Congressional Research Service Report RS22897 (13 June 2012). Washington, D.C.: Congressional Research Service.

Simon, C.J. and J.T. Warner. 2007. "Managing the All-Volunteer Force in a Time of War". The Economics of Peace and Security Journal. Vol. 2, No. 1, pp. 20-29.

Stiglitz, J.E. and L.J. Bilmes. 2008. The Three Trillion Dollar War: The True Cost of the Iraq Conflict. New York: W.W. Norton.

[VBA] Veterans Benefit Administration. Office of Performance Analysis and Integrity. 2012. "VA Benefits Activity, Veterans Deployed to the Global War on Terror." Through September 2012. Washington, D.C.: Veterans Benefit Administration. Office of Performance Analysis and Integrity.

Viscusi, W.K. and J.E. Aldy. 2003. "The Value of Statistical Life: A Critical Review of Market Estimates Throughout the World." Journal of Risk and Uncertainty. Vol. 27, No. 1, pp. 5-76. http://dx.doi.org/10.1023/A:1025598106257

Wheeler, W.T. 2011. "Unaccountable: Pentagon Spending on Post-9/11 Wars. http://costsofwar.org/sites/default/files/ articles/39/attachments/WheelerPentagonSpending.pdf [accessed 7 March 2014]. 